\title{
Block caving strategic risks
}

\author{
R.J. Butcher Barrick Gold of Australia Ltd, Australia \\ M. Fallon Barrick Gold of Australia Ltd, Australia
}

\section{Abstract}

Over the last 20 years many companies have investigated the use of block caving to extract low grade orebodies at depth. Despite the interest in these projects, few companies actually embark on the implementation of large scale caving due to the risk profiles. This paper discusses the strategic risks that must be taken into account before a company decides to use block caving.

\section{Introduction}

Today many international mining companies are either investigating the use of block caving as a method for future mining or implementing these projects. Despite the recent focus on the geotechnical design of caves, there are many other strategic risks that a company must account for before embarking on the construction of a block cave. This paper discusses the four key risks that have a significant impact on a company's decision to implement a block caving project. These include:

- corporate appetite/attitude for block caving

- corporate investment evaluation criterion used

- cavability risk

- impact of key commodities on operational costs.

The authors' do not discuss the impacts of Corporate Social Responsibility or Sovereign and Ownership risks on block caving projects, as these tend to be common to all large scale mining projects.

\section{$2 \quad$ Corporate appetite/attitude to block caving}

Despite block caving having the highest tonnage productivity and the lowest operating costs of all underground mining methods, many companies are risk adverse in their decision to bring these types of projects into production. Accordingly it is important to understand why many senior mining executives are hesitant to support a move towards block caving.

The final decision to execute a caving project is undertaken by the company's board following the recommendation from the Senior Leadership Team. Ultimately it is the Senior Leadership Team's perception of risk that influences the decision to construct a block cave. The two key factors influencing this risk perception is the large capital cost commitment and the long pay back periods. From the author's experience, the level of capital expenditure required for the underground mine can vary between US\$ 300 million to US\$ 1.1 billion. As a general rule, the capital expenditure for a large block cave should never be less than US\$600 million. Recent experience has shown that capital expenditures of below US\$ 500 million are normally associated with the development of a new block in the vicinity of an existing cave.

However, these expenditures only apply to the development of the underground mine and do not include the total project capital costs. The total capital expenditure required for a block cave project can vary significantly and is dependent on the complexity of the process plant and the total surface infrastructure required. A further consideration is that the initial ore production from many large caving projects is supplemented by ore feed from an adjacent open cut mine. In this instance the open cut pre-strip and fleet 
purchase costs should be added to the total pre-production capital expenditure. From the authors' experience it is not uncommon for the total pre-production capital expenditure to be between US\$ 3-5 billion for block cave projects.

Not only is it a decision for companies to commit to large quantities of capital expenditure, another major concern is that between $70-90 \%$ of the capital is spent before ore production commences. Even at the evaluation study stage, expenditures can be high because infrastructure such as exploration shafts and declines may be needed for geological and geotechnical purposes. At the feasibility study stage, costs of between US\$150-200 million are typical for medium to large scale projects. Compounding these risks is that large block caving projects are not immune from capital cost 'blow outs'. Butcher (2003) suggests that design and execution problems can easily result in a blow out of capital in the region of $30 \%$.

Another hurdle company executives need to consider before committing to a block caving project is the long construction and payback period times. Bartlett (2010) gives an example from the Palabora project stating that a large block cave can take up to 20 years before being brought into production. In the authors' experience pay back periods can vary from between 5-20 years, however, projects with pay back periods of less than 10 years tend to be associated where cave ore is supplemented with either open cut or sublevel caving ore. The ore supplement occurs during the construction and production ramp-up of the block cave.

Another aspect that influences corporate management's decision is the existing pipeline of projects in the company's portfolio. Block caving projects tend to consume considerable human, material, financial and time resources. From the authors' experience regardless of a company's size, it is difficult for most companies to implement more than one large caving project and two advanced studies at the same time due to the human, material, financial and time constraints. Bartlett (2010) demonstrates that such resources may have to be committed for between 10-20 years before a cave project becomes fully operational. In the current climate of skill shortages, committing large amounts of human capital to a single large mining project over a long time period incurs significant risk in terms of staff attraction and retention. In developing countries this challenge is compounded as sufficient operational and technical skills may not exist and necessitates the requirement for expatriate staff to be used.

From this discussion it is evident that a number of financial and physical hurdles exist for any company that may wish to embark on block caving projects. These human, capital and time barriers are prohibitive to junior and medium size producers and tend to limit the decision to undertake block caving to the major blue chip mining companies or to blue chip sponsored joint ventures. However, even as these projects are within the capacity of many of the larger international companies, block caving is still viewed as a high risk venture. In general, a company tends to stick to their established production profiles based either on open cut or underground stoping techniques. They tend not to consider the block caving projects due to the lack of technical expertise and knowledge in block caving. In essence these companies feel more comfortable approving high strip ratio pit cut backs because they have the skills and experience with this type of mining. In addition, should a company have a large pipeline of open cut projects there may be a rationale within the company's Senior Leadership Team that there are insufficient reasons or rewards to expose the company to the risks associated with block caving. However, there are conditions where a company must seriously consider block caving instead of open cut mining. These include where:

- there is insufficient land for waste dump construction

- the orebody is greater than $250 \mathrm{~m}$ below surface

- the mining cost of the open cut will be greater than US\$ $5 / t$

- there is a serious risk of slope instability

- there are major environmental concerns with open cut mines

- there is a combination of the above. 
Butcher (2003) states that it is normally the last cut back of an existing large deep pit that is normally in competition with a block cave.

All of the previous discussion highlights why companies are risk adverse in their decision to embark on block caving projects. However, it is important to understand the conditions that would make company executives favour block caving over other mining methods. The critical factor in this decision is previous experience in block caving within the company. Guest and Owen (1992) showed that companies such as De Beers, who have over 50 years experience in the construction and operation of block caves tended to favour it over other methods as their mines became deeper. It should be noted that previous experience does not necessarily have to be directly with block caving, as some companies have adopted a business model of using sublevel caving techniques prior to considering investing time and money in block caving projects. Companies such as Newcrest (Jones and Dunstan, 2011) and BHPB (Thin et al., 2006) have successfully used this approach. In particular, Newcrest's Ridgeway operation is one where the company built a successful track record using sublevel caving techniques for ten years before having the confidence to commit to a block caving project.

In the instance of a project with a large tonnage and low grade orebody adjacent to an existing operating open pit, and following an evaluation study that has been deemed it to be uneconomic for either open pit or conventional underground stoping mining techniques, then block caving should be considered as a viable option to maximise the value of the property. In this situation a company is faced with the decision to either undertake block caving, divest the mine or cease mining at the end of pit life. Calder et al. (2000) uses the Palabora project as example of this. As a generalisation the authors' find block caving is the preferred option above open pit cut backs when the grade of the orebody is above $0.5 \% \mathrm{Cu}$ equivalent and where the next pit push back has a strip ratio higher than 8:1.

\section{Corporate investment/evaluation criterion used}

A company will only commit to a block caving project if it adds significant value and increases its share price. Therefore it is evident that the methods and inputs used to determine the value of the project are a key strategic consideration. Today most mining projects are evaluated using the NPV criterion. In this regard Steffen (1997) states the value determined from the net present value (NPV) method is most sensitive to assumptions used for the income stream of the cash flow determination such as metal price and exchange rates. Since metal prices and exchanges can fluctuate throughout the life of a block caving project, selecting these parameters can be challenging and have a major impact on the investment decision. Figures 1, 2 and 3 show metal price and Foreign Exchange Fx trends over the last five years.

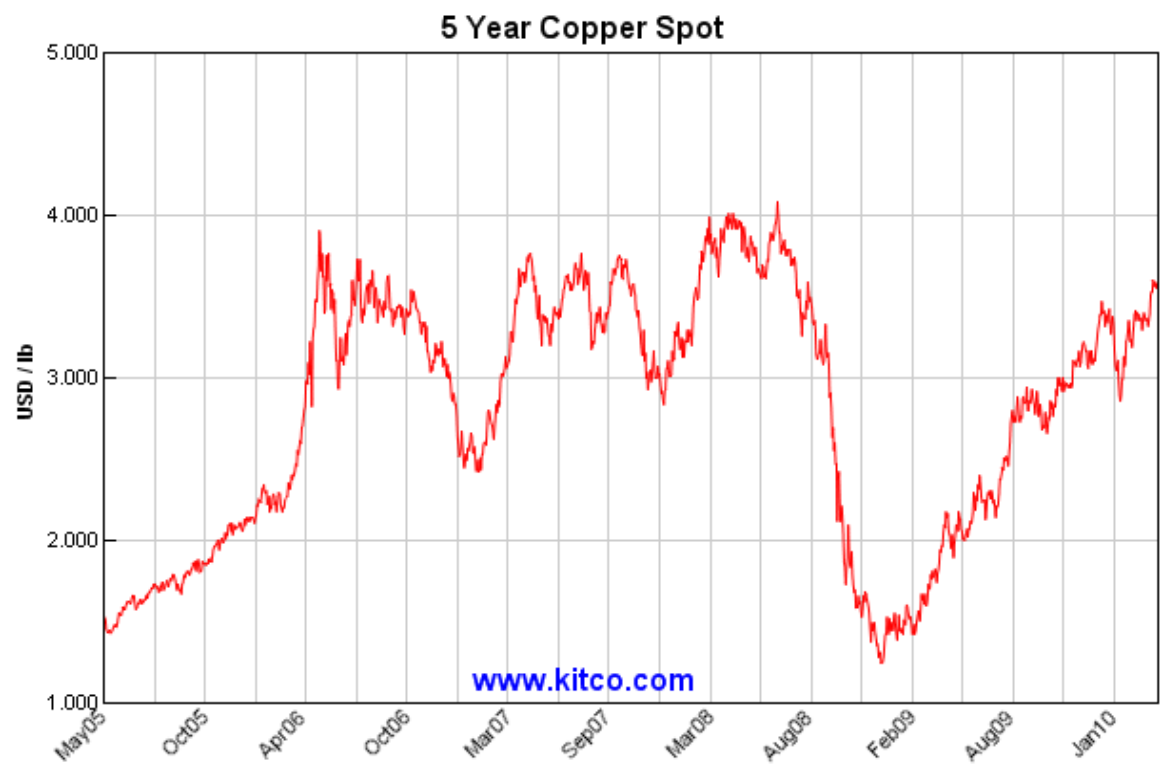

Figure 1 Copper price from 2005-2010 (Butcher and Smith, 2010) 


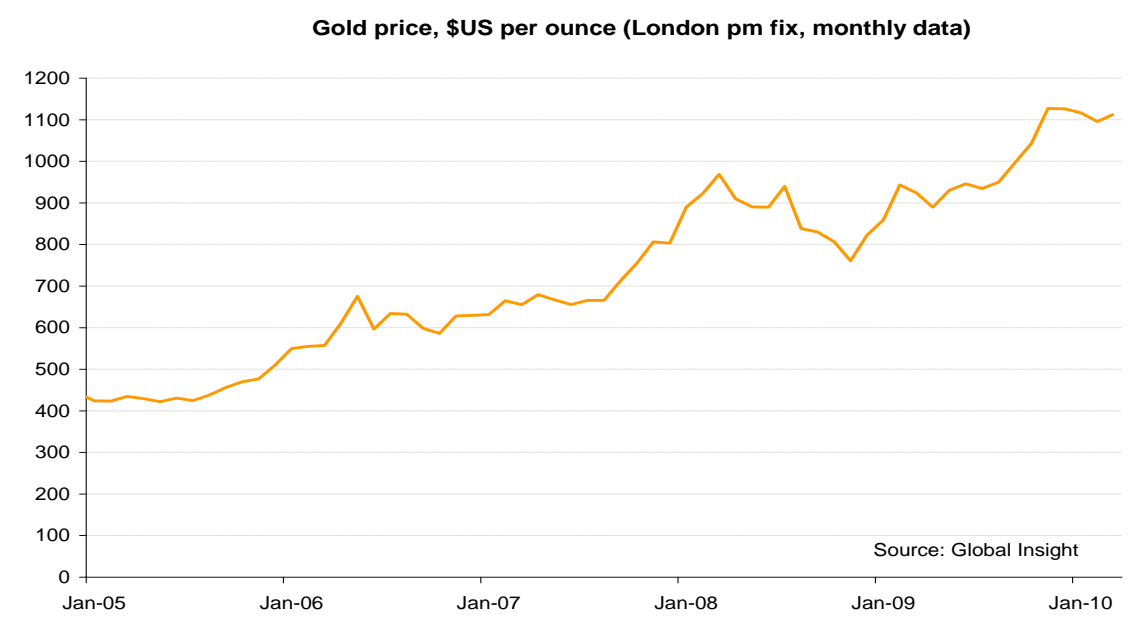

Figure 2 Gold prices from 2005-2010 (Butcher and Smith, 2010)

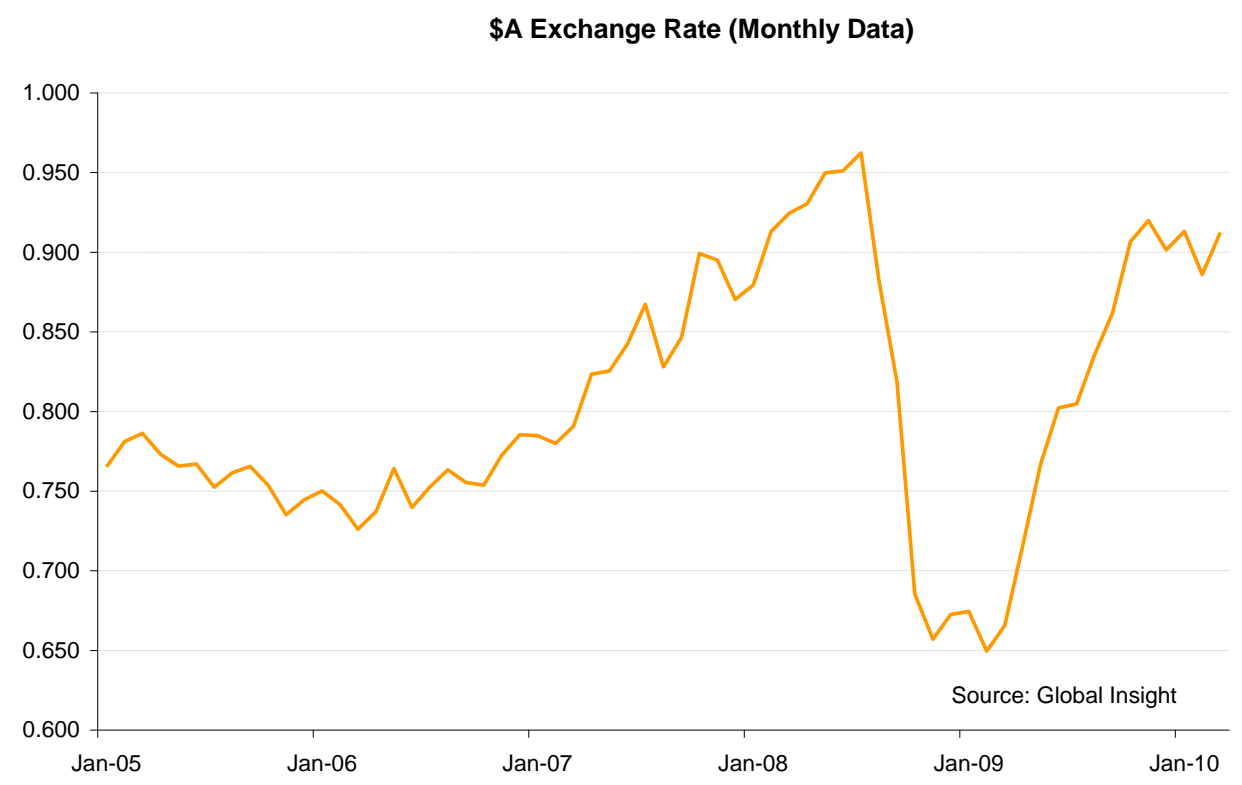

Figure 3 US/A\$ exchange rates from 2005-2010 (Butcher and Smith, 2010)

Butcher and Smith (2010) state that at low copper grades, between $0.4-0.8 \% \mathrm{Cu}$, at which large block caves are now being planned the long term copper prices will have to remain at least above US\$1.5 $\mathrm{lb}$ and preferably above US\$2.25 lb if many of these projects are to be viable.

Not only can the inputs into the NPV method have an impact on the development decision, it is also the NPV methodology of discounting over time that can significantly impact on the project value. In the authors' experience in an attempt to account for the risks, many block caving projects are evaluated using discount rates of between 5-7\% over a 20-25 year period. Steffen (1997) discusses this problem and suggests that long term projects should be evaluated using a combination of factors such as an acceptable marginal cost of production, acceptable share holder return as well as the traditional NPV criterion. Steffen (1997) also suggests that option values should be run to evaluate the project risks and opportunities. Even though Steffen (1997) suggests a practical solution to the disadvantages associated with using the traditional NPV method when evaluating block caving projects, pragmatic cognisance must be given to the share market's methodology of assessing the value a new block cave may have to the company portfolio. To determine the ultimate value of a company, many market analysts use the Net Asset Value (NAV) 
criterion. NAV can simply be defined as a company's net cash plus its total NPV. Therefore it is evident that any block caving project with a low or negative NPV will have a major impact on the total value of a company. In reality, no company undertakes a project that reduces its value and therefore it is only the strongest block caving projects that tend to be given the approval to go ahead. Based on the authors' experience it would appear that companies will not implement block caving projects unless the NPV is 1.0 to 1.3 times higher than the pre-production capital.

\section{$4 \quad$ Cavability risk}

The two main technical concerns for companies wishing to embark on block caving projects are:

- Will the orebody cave?

- The removal of large and oversize ore fragments that report to cave drawpoints.

Experience from Palabora (Ngidi and Boshoff, 2007) has shown that competent orebodies can be block caved efficiently and it appears that the key to dealing with large drawpoint fragments is to:

- undertake sufficient technical studies to predict the cave fragmentation and cave production profile

- purchase a secondary breakage fleet to deal with hang-ups in drawpoints

- have experienced secondary breakage crews with effective work and cave management systems.

The last point is the most important as Ngidi and Boshoff (2007) state that it can take up to three years to develop these skills if they do not exist within the company. Therefore a key strategy for dealing with large and oversize fragmentation in the cave should be the training of secondary breakage crews. From the authors' experience a large block cave project using a drawpoint demand strategy can have up to 50 personnel assigned to secondary breakage.

With respect to the cavability, much work has been done over the last 20 years in terms of the methods used to determine if an orebody will cave (Butcher, 2004). Experiences from Palabora have shown that even the most competent orebodies will cave if the undercut area is sufficiently large. In recent years the key questions regarding cavability have mainly related to:

- the size of the undercut to induce and propagate caving

- propagation of high/large caving blocks

- propagation of high/large caving blocks without leaving side wedge ore remnants

- slow cave propagation rates.

These issues are not new and have been a major concern for the last 40 years (de Nicola Escobar and Fishwick Tapia, 2000), and more recently brought to the afore with the North Parkes accident (Ross and van As, 2005). In recent years several companies have embarked on pre-conditioning orebodies to either assist cave propagation or for remnant removal. The effectiveness of using assisted or pre-conditioning methods over the last 40 years have had mixed results (Talu et al., 2010), and hence should not be relied upon to resolve high risk situations. In the authors' experience the risks associated with cavability of high/large orebodies can be mitigated by increasing the level of geotechnical investigation and design in the study stages of the block cave project. Butcher (2004) recommends a method to conduct a cavability assessment. The key components include:

- compilation of a detailed geotechnical model

- experiential and empirical cavability assessment

- detailed numerical cavability assessment (an example of which is shown in Figure 4). 


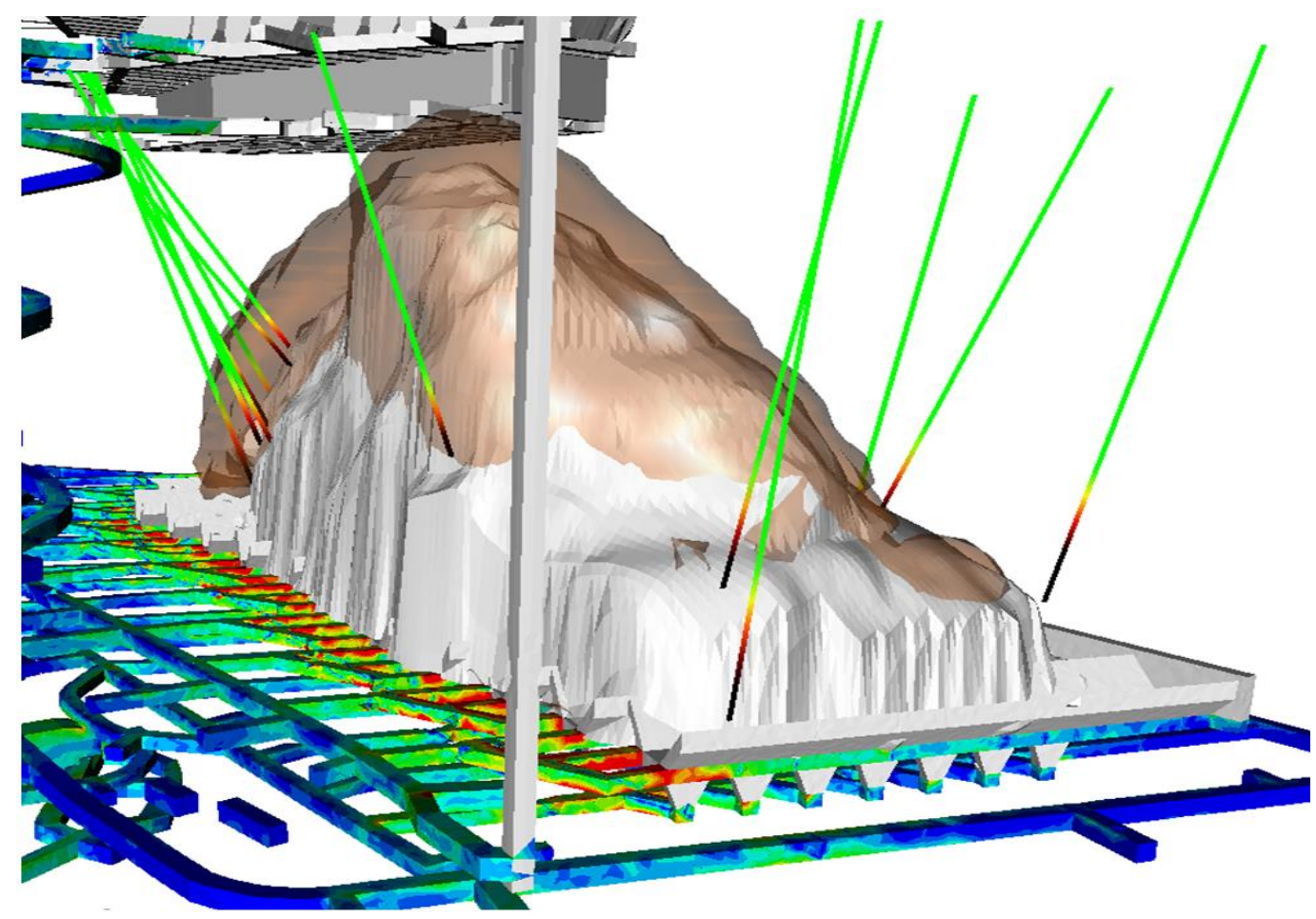

Figure 4 ABACUS numerical cavability analyst (after D. Beck, pers. comm., 2011)

Despite the advances in geotechnical techniques over the last two decades, it is the authors' experience that many large caving projects still only use empirical methods to determine cavability. Since these empirical methods were based on caves with lower block heights than what are currently planned today, it can be deduced that many of these projects are implemented with a reasonable degree of uncertainty.

The key question is what strategies should a company employ to mitigate this uncertainty, as the geotechnical assessment will only tell the mine engineer if a planned block cave will be at risk to cave propagation problems. A potential solution to the problem is to investigate strategic options in terms of the project configuration. These include:

- selection of a low lift cave

- panel cave, starting in weaker areas of the orebody

- sublevel caving wedge ore section of the orebody in conjunction with block caving

- increase block cave secondary blasting resources

- commence the project concurrent with an open cut mine in an attempt to reduce production pressure on the block cave during project ramp-up.

If the block cave is to be mined after completion of an open cut, then the following points could also be considered to mitigate the risks of slow cave propagation. These include:

- start the block cave sooner to reduce production hiatus

- process sub-grade stock piles from the open cut

- sublevel caving or open bench mining below the open cut as an intermediate measure before block caving

- mining of upper slope pit cut backs and ramp roll ups. 


\section{Impact of key commodities on perceived advantage}

One of the main attractions of block caving is the large economies of scale resulting from the high tonnage productivities and low operational costs. The high tonnage productivities directly relate to the limited need to drill, blast and crush drawpoint ore. In general the operation costs associated with a mature large block cave can be considered comparable with a deep large open cut with long hauls. However, this is dependent on fuel and labour costs.

The fact that block caves have the lowest operational costs has been known for many years. Laubscher (1994) describes block caving as the mining method with the lowest operational cost per tonne, while Butcher (2003) also stated that operational costs could be as low as US\$2.50/t for mature block caves. Barazza and Crorkan (2000) also confirmed this stating that operational costs could be as low as US\$2.58/t. More recently, operational costs for block caves now range between US\$ 4.70-9.00/t. However, for mines in developing countries, there are cases where the costs can be as low as US\$2.50/t. It is important to understand the key factors that influence the large range of block cave operational costs. These include:

- cave production capacity

- labour costs

- power costs

- fixed to variable cost ratio.

Assuming a well run cave project with limited drift and drawpoint repair, it is implicit that the higher the tonnage production capacity will result in lower operational costs. Costs also tend to reduce towards the end of the cave's life as fragmentation becomes finer and secondary breakage costs reduce. Typically at the start of the cave, the secondary breakage costs are approximately $30 \%$ of the total caving operational costs. From the authors' experience block cave costs tend to reduce by approximately $15 \%$ after the designed drawrate has been achieved. It should be remembered, it is only the variable component of the operational cost that is positively influenced by cave maturity. In most cave operations the variable costs are only about $40-60 \%$ of the total production costs. An understanding of the influence of labour and power costs can have on the block cave operational costs is also important.

To validate this statement the authors' conducted a first principle exercise on the costs at a deep level Australian block cave. The results indicated that labour and power directly and indirectly contributed up to $80-85 \%$ of the operational costs. It also is apparent that power costs contribute in the region of $20-25 \%$ of the total production costs. The exercise tested the impact on power costs if refrigeration and radon daughter suppression were required. The results indicated that the operational costs could be as high as US\$10/t with these options.

A global view of labour costs must also be considered, and from the authors' experience labour seems to

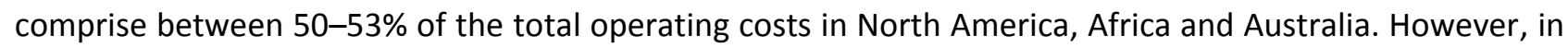
South America labour costs only tend to be in the vicinity of $30 \%$ of the operating costs. This fact is evident in the higher tonnage capacity and the lower operating cost block cave mines in South America, as these mines have operational costs below US\$ 6/t.

The key principle from this discussion is that the perceived advantage block caving has over other methods is, to some degree, reliant on external factors such as the labour market and power costs. It should also be recognised as caves get deeper the power costs could increase due to hoisting and ventilation needs.

\section{Conclusions}

This paper discussed a number of the strategic risks that must be considered by a company when evaluating a block caving project. It also discussed three of the main aspects that a board must account for before approving a caving project. All of the issues discussed are complex and the impacts, risks, 
resolutions and understanding is critical before a company can confidently commit its time, human and capital resources on block caving projects.

\section{References}

Barazza, M. and Crorkan, P. (2000) Esmeralda Mine Exploitation Project, in Proceedings MassMin 2000, G. Chitombo (ed), 29 October to 2 November 2000, Brisbane, Australia, Australasian Institute of Mining and Metallurgy, Melbourne, pp. 267-279.

Bartlett, P.J. (2010) Considerations in planning massive underground mines at depth, in Proceedings 2nd International Symposium on Block and Sublevel Caving (Caving 2010), Y. Potvin (ed), 20-22 April 2010, Perth, Australia, Australian Centre for Geomechanics, Perth, pp. 359-370.

Butcher, R.J. (2003) Cave Mining Geomechanics, Course Notes, October, Perth, Australian Centre for Geomechanics.

Butcher, R.J. (2004) DEESA, An approach to determine if an orebody will cave, in Proceedings MassMin 2004, A. Karzulovic and M. Alvaro (eds), 22-25 August, Santiago, Chile, Instituto de Ingenieros de Chile, Santiago, pp. 49-55.

Butcher, R.J. and Smith, G. (2010) Strategic considerations in Block Caving, in Proceedings 2nd International Symposium on Block and Sublevel Caving (Caving 2010), Y. Potvin (ed), 20-22 April 2010, Perth, Australia, Australian Centre for Geomechanics, Perth, pp. 231-236.

Calder, K., Townsend, P. and Russel, K. (2000) The Palabora Underground Mining Project, in Proceedings MassMin 2000, G. Chitombo (ed), 29 October to 2 November 2000, Brisbane, Australia, Australasian Institute of Mining and Metallurgy, Melbourne, pp. 219-227.

de Nicola Escobar, R. and Fishwick Tapia, M. (2000) An Underground Air blast - Codelco-Division Salvador, in Proceedings MassMin 2000, G. Chitombo (ed), 29 October to 2 November 2000, Brisbane, Australia, Australasian Institute of Mining and Metallurgy, Melbourne, pp. 279-289.

Guest, A.R. and Owen, K.C. (1992) Underground Mining of Kimberlite Pipes, in Proceedings XV CMMI Congress, Mining, Vol. 1, pp. 207-219.

Jones, C. and Dunstan, G. (2011) Developing the Ridgeway Deeps Project with an Operational Attitude Proceedings, in Proceedings 11th Underground Operators Conference 2011, AusIMM, 21-23 March, Canberra, Australia, Australasian Institute of Mining and Metallurgy, Melbourne, pp. 103-107.

Laubscher, D.H. (1994) Cave Mining - State of the Art, in Journal of the South African Institute of Mining and Metallurgy, Vol. 98(8), pp. 270-293.

Ngidi, S. and Boshoff, P. (2007) Cave Management and Secondary Breakage at Palabora Mining Company, in Proceedings 1st International Symposium on Block and Sub Level Caving: Cave Mining, 8-10 October 2007, Cape Town, South Africa, South African Institute of Mining and Metallurgy, pp. 161-173.

Ross, I. and van As, A. (2005) Northparkes Mine - Design, Sudden failure, Air blast and Hazard Management of the E26 Block Cave, in Proceedings 9th Underground Operators Conference 2005, AusIMM, 7-9 March, Perth, Australia, Australasian Institute of Mining and Metallurgy, Melbourne, pp. 7-21.

Steffen, O.K.H. (1997) Planning Open Pit Mines on a Risk basis, Journal SAIMM, March 1997.

Talu, S., van As, A., Seloka, W. and Henry, W. (2010) Lift 2 North extension cave performance, in Proceedings 2nd International Symposium on Block and Sublevel Caving (Caving 2010), Y. Potvin (ed), 20-22 April 2010, Perth, Australia, Australian Centre for Geomechanics, Perth, pp. 389-406.

Thin, I., Stone, C., Beck, D. and Hastings, N. (2006) Perseverance Mine: Past, Present and Deeper - Part III, in Proceedings 2nd International Seminar on Strategic versus Tactical Approaches in Mining, Y. Potvin (ed), 8-10 March 2006, Perth, Australia, Australian Centre for Geomechanics, Perth, Section 7, 15 p. 